\title{
Заюков I.B.,
}

д.е.н., доцент,

Вінницький національний технічний університет

ORCID: 0000-0001-7170-7159

Zivan@i.ua

\section{ОЦІНЮВАННЯ ВЗАЕМОЗВ'ЯЗКУ МІЖ СЕРЕДНЬОЮ ОЧІКУВАНОЮ ТРИВАЛІСТЮ ЖИТТЯ ТА ВВП}

Оиінювання взаємозв'язку між середньою очікуваною тривалістю життя та ВВП. Обтрунтовано важливість активізачії економічного розвитку України як фактору зростання середньо очікуваної тривалості життя. Акцентовано увагу на низькому значенні індексу рівня тривалості життя в Україні, порівняно з розвиненими країнами світу. Проаналізовано в динаміці статистичні дані щзодо середньо очікуваної тривалості життя та рівня валового внутрішнього продукту на душу населення за паритетом купівельної спроможності за окремими країнами-членами Організачії Економічного Співробітництва і Розвитку. Побудовано лінійну кореляційно-регресійну математичну модель взаємозв'язку між середньою очікуваною тривалістю життя $i$ ВВП на душу населення за ПКС за окремими краӥнами-членами ОЕСР. Оцінено параметри запропонованої моделі, які засвідчили, щзо вона є об'єктивною і статистично надійною. Обтрунтовано важливість фактору економічного росту в напряму забезпечення зростання середньо очікуваної тривалості життя в Украӥні, трунтуючись на досвіді розглянутих окремих краӥн-членів ОЕСР. Запропоновано рекомендащії щуодо економічного розвитку України в контексті забезпечення зростання середньо очікуваної тривалості життя в сучасних глобалізаційних умовах.

Ключові слова: тривалість життя, ВВП на душу населення, корелячія, модель

Рис. -2 , Табл. -3 , Літ. -15

Постановка проблеми. Важливим індикатором соціально-економічного розвитку є індекс рівня тривалості життя (Life Expectancy Index (LEI)). Так, найвищі значення LEI (в роках) станом на 01 січня 2020 року зафіксовані в таких країнах, як: Гонконг - 84,9; Японія - 84,6; Швейцарія - 83,8; Сінгапур, Іспанія - 83,6; Італія - 83,5; Австралія - 83,4 [1]. На жаль, значення LEI для України становить лише - 72,1 роки, що менше порівняно 3 вище наведеними країнами на 11,3-12,8 роки. Україна в рейтингу показника LEI займає 114 сходинку із 191 країн світу. Поруч із Україною, як свідчать дані ОOH, розміщаються такі країни із значенням LEI, як: Венесуела - 72,1; Сгипет - 72; Молдова - 71,9; Бутан - 71,8. Важливим резервом підвищення тривалості життя в Україні та в інших країнах, що розвиваються $є$ врахування сучасних глобальних викликів та нарощення ВВП. Адже, як свідчать дані [2-3], приріст ВВП на душу населення на 100 дол. США здатний різко збільшити очікувану тривалість життя. 
Аналіз останніх досліджень і публікацій. Вагомий внесок у дослідження теоретико-практичних проблем забезпечення зростання тривалості життя населення, наприклад, в контексті викликів глобального економічного розвитку зробили закордонні вчені, зокрема: (A. Bucci [4], R. Gordon [5], D. Heady [6], A. Hodge [7], T. Huang [7], J. Mierau [8], T. Piketty [9-10], S. Turnovsky [8], K. Prettner [11], A. Prskawetz [11], A. Thakur [12] та інші. Так, наприклад, вчений T. Piketty в працях [9-10] обгрунтовує тезу, що переважно забезпечення зростання ВВП на душу населення здатне призвести до покращення соціально-економічного розвитку, зокрема до підвищення тривалості життя. Відомі вітчизняні вчені, зокрема О. Амоша (O. Amosha), В. Антонюк (V. Antonyuk), C. Бандур (S. Bandur), Д. Богиня (D. Bogynia), I. Гнибіденко (I. Hnybidenko), О. Грішнова (O. Grishnova), М. Долішній (M. Dolishnii), О. Дороніна (O. Doronina), А. Колот (А. Kolot), I. Кравченко (I. Kravchenko), В. Куценко (V. Kutsenko), Е. Лібанова (Е. Libanova) [13], Л. Лісогор (L. Lisogor), В. Новіков (V. Novikov), О. Новікова (O. Novikova), Т. Орєхова (T. Oriekhova), В. Онікієнко (V. Onikiyenko), С. Пирожков (S. Pyrozhkov), H. Рингач (N. Rynhach), У. Садова (U. Sadova), Л. Семів (L. Semiv), М. Семикіна (M. Semykina), В. Стешенко (V. Steshenko), Л. Шаульська (L. Shaulska), Д. Шушпанов (D. Shushpanov) та ін. розглядали аналогічні проблеми і досліджували їх к контексті людського розвитку, якості життя тощо.

Так, академік НАН України Е. Лібанова зазначає, що за тридцять останніх років досить сильно змінилась тривалість життя в світі. Наприклад, вона зросла (при народженні) на 20,5 років для жінок і на 19,7 років для чоловіків, а в Україні, відповідно, лише на 5,9 і 1,3 роки. Наприклад, у Швейцарії, відповідно, на 11,5 і 13,3 роки [13]. 3 метою збільшення тривалості життя в Україні необхідно змінювати вектор демографічної та соціально-економічної політики, зокрема в напрямку підвищення якості життя. Зрозуміло, що основним резервом ії збільшення має стати активізація процесів в забезпеченні економічного розвитку України при врахуванні сучасних глобалізаційних викликів (інтеграція України до Європейського Союзу; посилення торгівельних зовнішньоекономічних відносин; врахування змін клімату і небезпечних пандемічних процесів, зокрема COVID-19; забезпечення імпорту і експорту інновацій та їх впровадження на вітчизняних підприємствах; оптимізація державного боргу тощо).

Формування цілей статті. Мета статті полягає в оцінюванні взаємозв'язку між середньою очікуваною тривалістю життя та ВВП на душу населення за ПКС (на основі даних окремих країн-членів ОЕСР) та в побудові відповідної лінійної кореляційнорегресійної математичної моделі.

Виклад основного матеріалу статті. 3 метою активізації процесів соціальноекономічного розвитку України в умовах глобалізації та збільшення тривалості життя необхідно проаналізувати наведені вище показники серед окремих країн-членів ОЕСР, a саме - середньо очікувану тривалість життя (СОТЖ) та валовий внутрішній продукт на душу населення за паритетом купівельної спроможності в постійних цінах 2015 року (ВВП ПКС). Так, спочатку проаналізуємо на рисунку 1 очікувану середню тривалість життя серед окремих країн ОЕСР та в Україні в 2018 році.

3 рисунку 1 видно, що серед наведених вище країн ОЕСР найбільшу СОТЖ має Швейцарія - 83,8 роки, Норвегія - 82,8 роки, Швеція - 82,6 роки, Канада - 82 роки. Україна мала зазначення відповідного показника в 2018 році на рівні - 71,76 роки, що на 10 і більше років менше порівняно з наведеними вище країнами ОЕСР. 


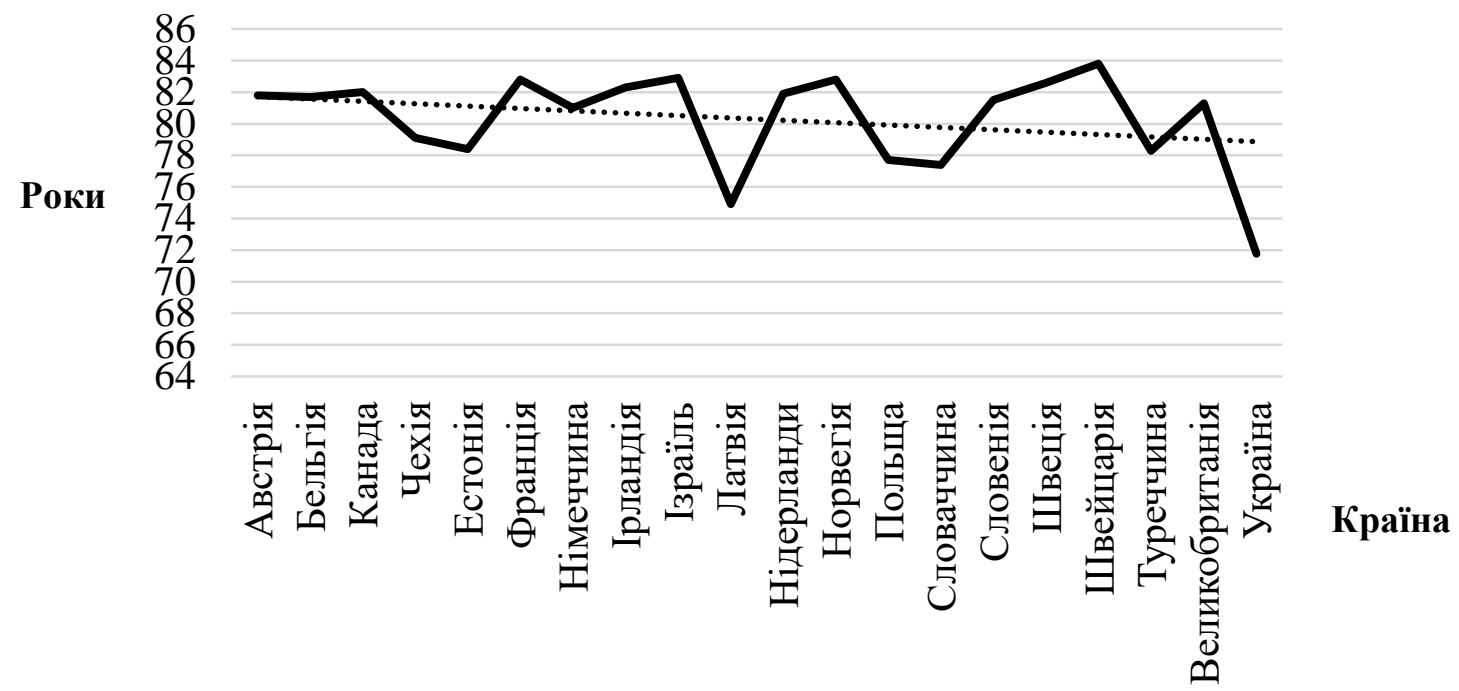

Рисунок 1. Значення СОТЖ населення окремих країн-членів ОЕСР та України в 2018 році, років

Джерело: складено автором за [14].

Далі проаналізуємо динаміку зміни показників за період 2010-2018 років СОТЖ та ВВП ПКС (в постійних цінах 2015 року, дол. США) в окремих країнах-членах ОЕСР та України (фрагмент-таблиця 1). Отже, дані таблиці 1 свідчать, що в 2018 році порівняно з 2010 роком наведені окремі країни ОЕСР мають позитивні тенденції щодо зростання СОТЖ та ВВП ПКС, зокрема це стосується і України.

Таблиця 1. Динаміка показників СОТЖ та ВВП ПКС в окремих країнах-членах ОЕСР та України в 2010-2018 роках

\begin{tabular}{|c|c|c|c|c|c|c|c|c|c|c|}
\hline \multirow{2}{*}{ Країна } & \multicolumn{9}{|c|}{ Роки } & \multirow{2}{*}{$\begin{array}{c}\text { Темп росту, } \\
2018-2010 \text { pp., } \\
\%\end{array}$} \\
\hline & 2010 & 2011 & 2012 & 2013 & 2014 & 2015 & 2016 & 2017 & 2018 & \\
\hline \multicolumn{11}{|c|}{ Австрія } \\
\hline COTЖ $^{1}$ & 80,7 & 81,1 & 81 & 81,2 & 81,6 & 81,3 & 81,7 & 81,7 & 81,8 & 101,4 \\
\hline ВВП ПКС ${ }^{2}$ & 48907,7 & 50172,4 & 50287,3 & 49998,0 & 49935,7 & 49942,1 & 50292,9 & 51176,1 & 52243,2 & 106,8 \\
\hline \multicolumn{11}{|c|}{ Бельгія } \\
\hline СОТЖ & 80,3 & 80,7 & 80,5 & 80,7 & 81,4 & 81,1 & 81,5 & 81,6 & 81,7 & 101,7 \\
\hline ВВП ПКС & 44813,0 & 44986,1 & 45037,1 & 45033,1 & 45539,9 & 46201,7 & 46551,6 & 47117,2 & 47752,8 & 106,6 \\
\hline \multicolumn{11}{|c|}{ Канада } \\
\hline СОТЖ & 81,1 & 81,3 & 81,5 & 81,7 & 81,8 & 81,9 & 82 & 82 & 82 & 101,1 \\
\hline ВВП ПКС & 42170,0 & 43073,0 & 43358,2 & 43901,7 & 44710,0 & 44670,1 & 44609,4 & 45416,9 & 45868,2 & 108,8 \\
\hline$\cdots$ & $\cdots$ & $\cdots$ & $\cdots$ & $\cdots$ & $\cdots$ & $\cdots$ & $\cdots$ & $\cdots$ & $\cdots$ & $\cdots$ \\
\hline \multicolumn{11}{|c|}{ Великобританія } \\
\hline СОТЖ & 80,6 & 81 & 81 & 81,1 & 81,4 & 81 & 81,2 & 81,3 & 81,3 & 100,9 \\
\hline ВВП ПКС & 39959,4 & 40133,4 & 40439,1 & $\begin{array}{|ll|}41 & 064,7 \\
\end{array}$ & 41919,2 & 42571,7 & 42950,0 & 43438,1 & 43720,0 & 109,4 \\
\hline \multicolumn{11}{|c|}{ Україна } \\
\hline СОТЖ & 70,44 & 71,02 & 71,15 & 71,37 & 71,37 & 71,38 & $\begin{array}{l}71,68 \\
\end{array}$ & 71,98 & 71,76 & 101,9 \\
\hline $\mathrm{BB \Pi}^{3}$ & 2974,40 & 3570,80 & 3856,80 & \begin{tabular}{|l|}
4030,30 \\
\end{tabular} & 3014,60 & 2115,40 & 2185,90 & 2640,30 & 3095,20 & 104,1 \\
\hline
\end{tabular}

Джерело: складено та розраховано автором за [14-15].

Примітка: 1 - СОТЖ виражена в роках; 2 - ВВП ПКС - валовий внутрішній продукт на душу населення за ПКС в цінах 2015 року; 3 - для України значення ВВП на душу населення наведено без врахування ПКС. 
Так, за відповідний період в Україні СОТЖ зросла на 1,9\%, а ВВП на душу населення на 4,1\%. Темпи росту в Україні за показником ВВП на душу населення $\epsilon$ значно менші порівняно з наведеними країнами ОЕСР. При цьому, варто зауважити, що і обсяги ВВП в десять і більше разів менші, без врахування ПКС.

Далі проаналізуємо тісноту зв'язку між СОТЖ та ВВП ПКС в окремих країнах ОЕСР. Для цього використаємо метод дослідження - кореляційно-регресійний аналіз. Результати дослідження наведені в таблиці 2.

Таблиця 2. Оцінка тісноти зв'язку та його надійності між СОТЖ та ВВП ПКС в окремих країнах ОЕСР (за даними 2010-2018 років)

\begin{tabular}{|c|c|c|c|}
\hline \multirow{3}{*}{ Країна } & \multicolumn{3}{|c|}{ Показники } \\
\hline & \multirow{2}{*}{$\begin{array}{c}\text { Коефіцієнт } \\
\text { кореляції (R) }\end{array}$} & \multicolumn{2}{|c|}{ Критерій Фішера } \\
\hline & & $F_{p}$ & $\mathrm{~F}_{\mathrm{kp}}$ \\
\hline Австрія & 0,748775 & 2,988838 & \multirow{19}{*}{2,364624} \\
\hline Бельгія & 0,896267 & 5,346598 & \\
\hline Канада & 0,950406 & 8,085063 & \\
\hline Чехія & 0,819574 & 3,784457 & \\
\hline Естонія & 0,968124 & 10,22638 & \\
\hline Франція & 0.771877 & 3.212152 & \\
\hline Німеччина & 0.760583 & 3.099488 & \\
\hline Ірландія & 0.960992 & 9.19292 & \\
\hline Ізраїль & 0,96646 & 9,956587 & \\
\hline Латвія & 0.968436 & 10.27934 & \\
\hline Нідерланди & 0.717032 & 2.721632 & \\
\hline Норвегія & 0,94935 & 7,993529 & \\
\hline Польща & 0,834656 & 4,009459 & \\
\hline Словаччина & 0,930101 & 6,69965 & \\
\hline Словенія & 0,674436 & 2,416778 & \\
\hline Швеція & 0,932892 & 6,853138 & \\
\hline Швейцарія & 0,937288 & 7,11461 & \\
\hline Туреччина & 0,877986 & 4,852731 & \\
\hline Великобританія & 0,721127 & 2.753916 & \\
\hline
\end{tabular}

Джерело: розрахунки автора.

Отже, дані таблиці 2 свідчать, що між наведеними показниками по окремим країнам ОЕСР існує досить тісний зв'язок від 0,675 в Словенії до 0,97 в Естонії, Ізраїлі, Латвії. Крім того, Критерій Фішера задовольняє умову $\left(\mathrm{F}_{\mathrm{p}}>\mathrm{F}_{\mathrm{kp}}\right)$, що свідчить про статистичну значимість наявної залежності між СОТЖ та ВВП ПКС. Далі побудуємо лінійну кореляційно-регресійну модель, яка б дала можливість прогнозувати СОТЖ залежно від ВВП ПКС (модель). Для побудови моделі скористаємось статистичними даними ОЕСР [14] та інформацією, яка наведена в таблиці 1 (таблиця 3). 
Таблиця 3. Вихідні дані для побудови кореляційно-регресійної моделі

\begin{tabular}{|c|c|c|c|c|c|}
\hline$^{1}{ }^{1}$ & $\mathrm{Y}$ & $\mathrm{x}_{1}$ & $\mathrm{Yx}_{1}$ & $\mathrm{x}_{1}{ }^{2}$ & $\mathrm{Y}^{2}$ \\
\hline 1 & 81,80 & 52243,2 & 4273496,2 & 2729355063 & 6691,24 \\
\hline 2 & 81,70 & 47752,8 & 3901402,77 & 2280328749 & 6674,89 \\
\hline 3 & 82,00 & 45868,2 & 3761194,6 & 2103894228 & 6724 \\
\hline 4 & 79,10 & 37440,0 & 2961503,96 & 1401753563 & 6256,81 \\
\hline 5 & 78,40 & 33293,8 & 2610236,68 & 1108479462 & 6146,56 \\
\hline 6 & 82,80 & 42543,0 & 3522556,45 & 1809902790 & 6855,84 \\
\hline 7 & 81,00 & 49827,3 & 4036011,95 & 2482760620 & 6561 \\
\hline 8 & 82,30 & 80670,2 & 6639158,08 & 6507682375 & 6773,29 \\
\hline 9 & 82,90 & 37253,8 & 3088338,97 & 1387844668 & 6872,41 \\
\hline 10 & 74,90 & 28176,7 & 2110438,39 & 793929103,5 & 5610,01 \\
\hline 11 & 81,90 & 53217,7 & 4358532,23 & 2832126969 & 6707,61 \\
\hline 12 & 82,80 & 61665,4 & 5105894,19 & 3802620169 & 6855,84 \\
\hline 13 & 77,70 & 30259,5 & 2351162,65 & 915636950,3 & 6037,29 \\
\hline 14 & 77,40 & 32541,1 & 2518681,3 & 1058923328 & 5990,76 \\
\hline 15 & 81,50 & 35556,7 & 2897873,65 & 1264281183 & 6642,25 \\
\hline 16 & 82,60 & 50472,5 & 4169032,16 & 2547477727 & 6822,76 \\
\hline 17 & 83,80 & 68580,0 & 5747005,49 & 4703218845 & 7022,44 \\
\hline 18 & 78,30 & 28410,8 & 2224562,76 & 807171463,6 & 6130,89 \\
\hline 19 & 81,30 & 43720,0 & 3554438,62 & 1911441213 & 6609,69 \\
\hline Рaзом & 1534,20 & 859492,9 & 69831521,1 & 42448828469 & 123985,6 \\
\hline
\end{tabular}

Джерело: складено та розраховано автором.

Примітка: 1 - розуміється країни члени ОЕСР, наприклад, під № 1 - країна - Австрія; Ү - значення СОТЖ в 2018 році (для Австрії - 81,8 роки); х 1 - ВВП ПКС (наприклад, для Австрії - 52243,2 дол. США). Відповідно до даних таблиці 3 була побудована кореляційно-регресійна модель взаємозв'язку між СОТЖ та ВВП ПКС, яка має вигляд:

$$
Y=75,29943+0,00012043 \times 1
$$

де Y - СОТЖ, років; х 1 - ВВП ПКС (в постійних цінах 2015 року), дол. США.

3 метою проведення верифікації зазначеної моделі наведемо розраховані показники, зокрема це: загальна дисперсія $\left(\mathrm{G}_{\mathrm{e}}{ }^{2}\right)-5,423$; факторна дисперсія без теоретичних значень $\left(\mathrm{G}_{\mathrm{y}}{ }^{2}\right)-2,705$; коефіцієнт кореляції $(\mathrm{R})-0,7089$; коефіцієнт детермінації $\left(\mathrm{R}^{2}\right)$ - 0,5025; розраховане значення критерію Фішера $\left(\mathrm{F}_{\mathrm{p}}\right)-3,893171$; табличне значення критерію Фішера $\left(\mathrm{F}_{\mathrm{kp}}\right)-2,109816$. Таким чином, між СОТЖ і ВВП ПКС зафіксовано достатньо вагомий зв'язок, а проведена верифікація моделі свідчить про її статистичну значущість і надійність. Так, при збільшенні ВВП ПКС на 1 тис. дол. США СОТЖ має зрости на 0,00012043 роки. Далі проаналізуємо на рисунку 2 фактичні дані СОТЖ та прогнозовані (відповідно до даних 2018 року) використовуючи наведену вище модель за окремо взятими країнами-членами ОЕСР. 


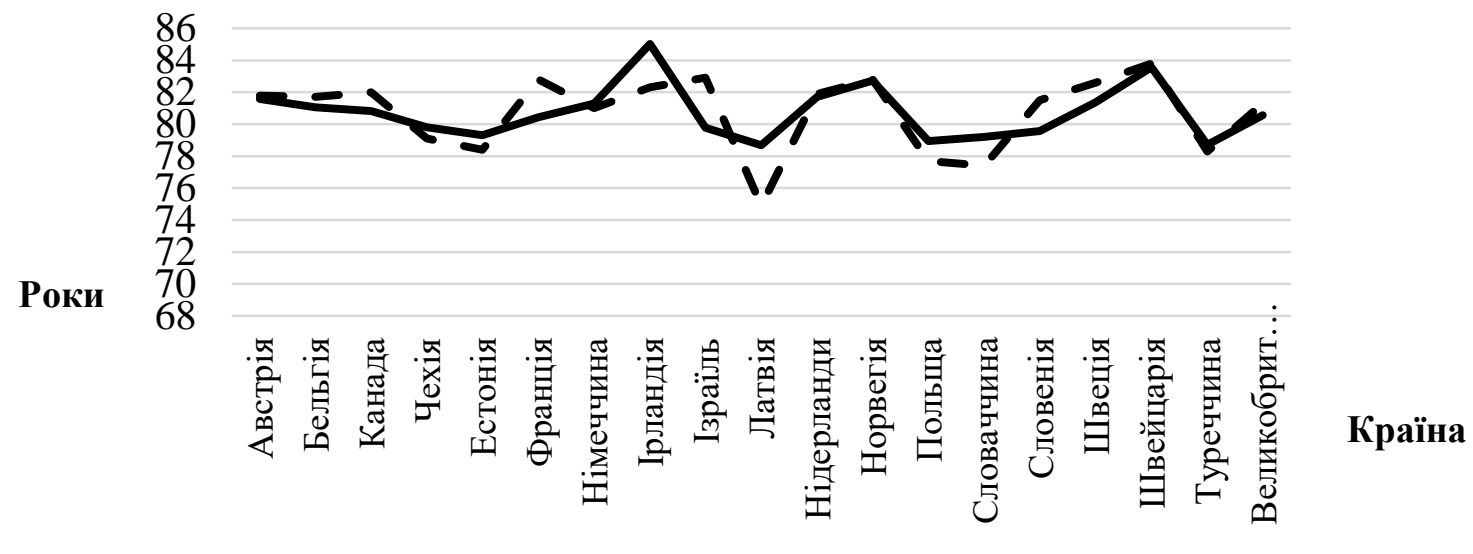

- - Фактичні дані, роки Прогнозовані дані, роки

Рисунок 2. Фактичні дані СОТЖ в окремих країнах ОЕСР та прогнозовані (відповідно до даних 2018 року)

Джерело: складено та розраховано автором за [14].

Дані, які наведені на рисунку 2 графічно ілюструють об’єктивність та надійність запропонованої моделі, яка, додатково, підтверджує гіпотези закордонних і вітчизняних вчених щодо існування вагомого зв'язку між СОТЖ та ВВП ПКС. Аналіз відповідної залежності для України за період 2010-2018 роки засвідчив, що існує обернена тенденція, тобто із збільшенням СОТЖ - ВВП на душу населення (без врахування ПКС) знижується. Відповідна модель має вигляд:

$$
\mathrm{Y}=\mathbf{7 2 , 0 3 2 4}-\mathbf{0 , 0 0 2 2 4 0 4 x}
$$

де Y - СОТЖ в Україні, років; х 1 - ВВП на душу населення в Україні, дол. США.

Основними параметрами, що оцінюють надійність моделі, на прикладі України, $\epsilon$, зокрема: коефіцієнт кореляції $(\mathrm{R})$ - «мінус» 0,833 ; коефіцієнт детермінації $\left(\mathrm{R}^{2}\right)$ - 0,6939; розраховане значення критерію Фішера $\left(\mathrm{F}_{\mathrm{p}}\right)-3,983341$; табличне значення критерію Фішера $\left(\mathrm{F}_{\mathrm{kp}}\right)-2,364624$. Отже, отримані результати дослідження та побудована модель дає можливість врахувати Україні досвід проаналізованих окремих країн-членів ОЕСР, зокрема щодо активізації процесів забезпечення економічного розвитку в сучасних глобалізаційних умовах. Це дасть можливість збільшити СОТЖ в Україні і поступово наближатись до обсягів і темпів росту ВВП ПКС розвинених країн світу.

Висновки. Важливою умовою забезпечення соціально-економічного розвитку будь-якої країни світу є проведення ефективної політики направленої на підвищення якості життя, зокрема зростання СОТЖ. Дані розглянутих країн-членів ОЕСР в статті доводять, що вони проводять стабільну політику щодо формування передумов зростання СОТЖ та ВВП ПКС. Це є основою підвищення рівня людського розвитку в цих країнах, a, отже, i сприятливо впливатиме на подальше їх соціально-економічне зростання. Прикладом цього $є$ досвід країн, які за останні декілька десятирічь змогли реалізувати реформи, які призвели до «економічного дива», наприклад, Гонконг, Китай, Сінгапур, Тайвань та інші. Такі країни, як: Гонконг, Сінгапур нині займають найвищі сходинки не тільки в рейтингу індексу рівня тривалості життя, але і в рейтингах розвитку економіки. На жаль, Україна протягом останніх тридцяти років незалежності, не змогла використати досвід зазначених країн щодо активізації економічних реформ, що б могло стати базою 
для збільшення середньо очікуваної тривалості життя. Україна має менше значення СОТЖ на 10 і більше років порівняно з розвиненими країнами.

Крім того, обсяг ВВП на душу населення за ПКС також в десять і більше разів менше, ніж в розвинених країнах світу, що істотно гальмує людський розвиток України. Тому надзвичайно важливим $є$ посилення уваги Уряду України на необхідність прискорення процесів активізації економічного розвитку, зокрема забезпечення зростання обсягів ВВП, що стане базою збільшення СОТЖ. Цю тезу обгрунтовано в роботі з позиції здійснення оцінювання взаємозв'язку між СОТЖ і ВВП на душу населення за ПКС, що дало можливість побудувати відповідну модель. Найбільше значення коефіцієнтів кореляції (R) між цими показниками зафіксовано в таких країнах, як: Ізраїль, Латвія, Естонія - 0,97; Ірландія - 0,96; Канада - 0,95. Отже, наприклад, проаналізовані статистичні дані Ізраїлю за 2010-2018 роки засвідчили, що СОТЖ на 94\% залежить від обсягів ВВП на душу населення за ПКС (в постійних цінах 2015 року). Розроблена кореляційна модель дала можливість зробити такий висновок, що при збільшенні продуктивності праці на 1 тис. дол. США СОТЖ зростатиме на 0,00012043 роки.

На основі побудованої кореляційної моделі та статистичних даних за окремими країнами-членами ОЕСР, зокрема Австрії, Бельгії, Канади, Швейцарії, Туреччини, Великобританії (всього обрано 19 країн) було спрогнозовано значення СОТЖ, що дало можливість провести графічний аналіз фактичних і прогнозованих даних. Даний аналіз та ії̈ верифікація, засвідчив, що модель є статистично значущою і надійною. Дана модель, на жаль, не може бути використана для прогнозування СОТЖ для України. Так, проведений кореляційно-регресійний аналіз за відповідними показниками в 2010-2018 роках (без врахування ПКС) засвідчив, що математично в моделі зафіксована обернена тенденція, ніж в розглянутих країнах-членах ОЕСР. Тобто із зростанням обсягів ВВП, як засвідчили статистичні дані, СОТЖ буде знижуватись. Це свідчить про необхідність змінювати вектор державної економічної політики України. Так, пропонується в парадигмі економічного розвитку країни посилити такі аспекти, як: збільшувати обсяги експорту продукції з високою доданою вартістю та суттєво його обмежувати з низькою доданою вартістю; реалізовувати політику протекціонізму у всіх сферах господарського життя; протидіяти сучасним глобалізаційним процесам, що несуть загрозу Україні, зокрема економічним кризам, пандеміям тощо; реалізовувати механізми щодо залучення зовнішніх і внутрішніх інвестицій з метою розвитку економіки, зокрема впроваджувати і реалізовувати на вітчизняних підприємствах реальні інноваційні продукти; враховувати сучасний досвід країн, які змогли реалізувати ефективні економічні реформи, зокрема це стосується і питань пошуку резервів зростання СОТЖ.

Перспективи подальших досліджень. Важливим аспектом оцінювання взаємозв'язку між середньою очікуваною тривалістю життя і ВВП на душу населення за ПКС залишається пошук резервів зростання економіки України, зокрема ії тіньового сектору, зниження смертності населення та підвищення його якісних характеристик.

\section{СПИСОК ВИКОРИСТАНИХ ДЖЕРЕЛ}

1. Life Expectancy Index 2020. Rating of countries in the world by life length level. URL: http://hdr.undp.org//.

2. Preston S. The changing relationship between mortality and the level of economic development. Int J Epidemiol. 2007; 36: 484-490. 
3. Linden M., Ray D., Life expectancy effects of public and private health expenditures in OECD countries 1970-2012: Panel time series approach. Economic Analysis and Policy. 2017. - URL: http://dx.doi.org/10.1016/j.eap.2017.06.005.

4. Piketty T. Capital in the twenty-first century. Cambridge, MA: Belknap Press of Harvard University Press; 2014.

5. Piketty T. About capital in the twenty-first century. American Economic Review. 2015; 105(5): 48-53.

6. Bucci A. Product proliferation, population, and economic growth. Journal of Human Capital. 2015; 9: 170-197.

7. Gordon R. The rise and fall of American growth: The U.S. standard of living since the Civil War. Princeton, NJ: Princeton University Press; 2016.

8. Heady D., Hodge A. The effect of population growth on economic growth: A metaregression analysis of the macroeconomic literature. Population and Development Review. 2009; 35: 221-248.

9. Huang T., Xie Z. Population and economic growth: A simultaneous equation perspective. Applied Economics. 2013; 45: 3820-3826.

10. Mierau J., Turnovsky S. Demography, growth and inequality. Economic Theory. 2014; 55: 29-68.

11. Prettner K., Prskawetz A. Demographic change in models of endogenous economic growth: A survey. Central European Journal of Operations Research. 2010; 18: 593-608.

12. Thakur A. Kassam A., Stoop W. Modifying rice crop management to ease water constraints with increased productivity, environmental benefits, and climate resilience. Agriculture, Ecosystems \& Environment. 2016; 235; 101-104.

13. Національна академія наук України. Інститут демографії та соціальних досліджень ім. М. В. Птухи. Елла Лібанова: Нас має бути не більше, ми маємо жити довше і краще. - URL: https://idss.org.ua/index.

14. Organization for Economic Cooperation and Development. Find, comparare and share the latest OECD data: charts, maps, tables and related publication. - URL: https://data.oecd.org/.

15. Офіційний сайт Державної служби статистики України. Населення та міграція. Національні рахунки. - URL: http://www.ukrstat.gov.ua/.

\section{Reference}

1. Life Expectancy Index 2020. Rating of countries in the world by life length level. URL: http://hdr.undp.org//.

2. Preston S. The changing relationship between mortality and the level of economic development. Int J Epidemiol. 2007; 36: 484-490.

3. Linden M., Ray D., Life expectancy effects of public and private health expenditures in OECD countries 1970-2012: Panel time series approach. Economic Analysis and Policy. 2017. - URL: http://dx.doi.org/10.1016/j.eap.2017.06.005.

4. Piketty T. Capital in the twenty-first century. Cambridge, MA: Belknap Press of Harvard University Press; 2014.

5. Piketty T. About capital in the twenty-first century. American Economic Review. 2015; 105(5): 48-53.

6. Bucci A. Product proliferation, population, and economic growth. Journal of Human Capital. 2015; 9: 170-197.

7. Gordon R. The rise and fall of American growth: The U.S. standard of living since the Civil War. Princeton, NJ: Princeton University Press; 2016. 
8. Heady D., Hodge A. The effect of population growth on economic growth: A metaregression analysis of the macroeconomic literature. Population and Development Review. 2009; 35: 221-248.

9. Huang T., Xie Z. Population and economic growth: A simultaneous equation perspective. Applied Economics. 2013; 45: 3820-3826.

10. Mierau J., Turnovsky S. Demography, growth and inequality. Economic Theory. 2014; 55: 29-68.

11. Prettner K., Prskawetz A. Demographic change in models of endogenous economic growth: A survey. Central European Journal of Operations Research. 2010; 18: 593-608.

12. Thakur A. Kassam A., Stoop W. Modifying rice crop management to ease water constraints with increased productivity, environmental benefits, and climate resilience. Agriculture, Ecosystems \& Environment. 2016; 235; 101-104.

13. Ptoukha Institute for Demography and Social Studies of the National Academy of Sciences of Ukraine. Ella Libanova: There should be no more of us, we should live longer and better. - URL: https://idss.org.ua/index.

14. Organization for Economic Cooperation and Development. Find, comparare and share the latest OECD data: charts, maps, tables and related publication. - URL: https://data.oecd.org/.

15. Official site of the State Statistics Service of Ukraine. Population and migration. National accounts. - URL: http://www.ukrstat.gov.ua/.

\section{Заюков И.В.}

\section{ОЦЕНКА ВЗАИМОСВЯЗИ МЕЖДУ СРЕДНЕЙ ОЖИДАЕМОЙ ПРОДОЛЖИТЕЛЬНОСТИ ЖИЗНИ И ВВП}

Обоснована важность активизации экономического развития Украины как фактора роста средне ожидаемой продолжительности жизни. Акиентировано внимание на низком значении индекса уровня продолжстельности жизни в Украине по сравнению с развитыми странами мира. Проанализированы в динамике статистические данные по средне ожидемой продолжительности жизни и уровня валового внутреннего продукта на душу населения по паритету покупательной способности по отдельным странам-членам ОЭСР. Построено линейную корреляиионно-регрессионную математическую модель взаимосвязи между средне ожидаемой продолжительности жизни и ВВП на душу населения по ППС по отдельным странам-членам ОЭСР. Оченены параметры предложенной модели, которые показали, что она является объективной и статистически надежной. Обоснована важность фактора экономического роста в направлении обеспечения роста средне ожидаемой продолжительности жизни в Украине, основываясь на опыте рассмотренных отдельных стран-членов ОЭСР. Предложены рекомендации по экономическому развитию Украины в контексте обеспечения роста средне ожидаемой продолжительности жизни в современных глобализационных условиях.

Ключевье слова: продолжительность жизни, ВВП на душу населения, корреляция, модель

\section{Zayukov}

\section{ASSESSMENT OF RELATIONSHIP BETWEEN AVERAGE LIFE EXPECTED AND GDP}

The importance of intensifying the economic development of Ukraine as a factor in increasing average life expectancy is substantiated. Emphasis is placed on the low value of the life expectancy index in Ukraine, compared to developed countries. The statistics on the average life expectancy and the level of gross domestic product per capita at purchasing power parity by individual member countries of the Organization for Economic Cooperation and Development are analyzed in the dynamics. A linear correlation-regression mathematical model of the relationship between life expectancy and GDP per capita for PPPs for individual OECD member countries has been constructed. The parameters of the proposed model were evaluated, which proved that it is objective and statistically reliable. The importance of the factor of economic growth in the direction of ensuring the growth of average life expectancy in Ukraine is substantiated, based on the experience of the considered individual OECD member countries. Recommendations for the economic development of Ukraine in the context of ensuring the growth of average life expectancy in today's globalization.

Keywords: life expectancy, GDP per capita, correlation, model 